\title{
Morphometric and stereological assessment of the effects of titanium dioxide nanoparticles on the mouse testicular tissue
}

\author{
Khorsandi L ${ }^{1,2}$, Orazizadeh $\mathrm{M}^{2}$, Mansouri E ${ }^{1,2}$, Hemadi $\mathrm{M}^{3}$, Moradi-Gharibvand $\mathrm{N}^{2}$ \\ Cell \& Molecular Research Center, Faculty of Medicine, Ahvaz Jundishapur University of Medical Sciences, \\ Ahvaz,Iran.layasadat@yahoo.com
}

\section{ABSTRACT}

OBJECTIVE: To evaluate the effects of titanium dioxide nanoparticles (TNPS) on morphometric and stereological parameters of mouse testis.

BACKGROUND: TNPs are increasingly used in sunscreens, biosensors, food additives, pigments, rubber manufacture, and electronic materials. However, the potential toxicity of these nanoparticles is not well understood. METHODS: Experimental Groups (TNP-1, TNP-2 and TNP-3) received one of the following treatments daily for 35 days: 75,150 and $300 \mathrm{mg} / \mathrm{kg}$ TNPs respectively. Right testis from each animal was fixed in bouin's solution for measurement of total volume of testis, total volume of seminiferous tubules, total volume of interstitial tissue and total number of Leydig cells by stereological methods. Seminiferous tubule diameter and seminiferous epithelium height were assessed by morphometrical method. The left testicles were homogenized for measurement of testosterone concentration. RESULTS: There was a significant decrease in the weight of testicles in TNP-3 groups. The stereological and morphometrical parameters were significantly changed in TNP-2 and TNP-3 groups. TNP-2 and TNP-3 groups also showed a significant decrease in testosterone concentrations $(p<0.05)$.

CONCLUSION: This study had demonstrated that TNPS could change stereological and morphometrical parameters of the seminiferous tubules and reduce the number of Leydig cells and testosterone concentration (Tab. 3, Fig. 3, Ref. 35). Text in PDF www.elis.sk. KEY WORDS: zinc oxide nanoparticles, seminiferous tubules, Leydig cells, stereology.

\section{Introduction}

Spermatogenesis is a complex process of germ cell proliferation and differentiation, which leads to the production and release of spermatozoa from the testis. This elaborate process depends on hormonal and dynamic interactions between somatic cells and germ cells of the testis. The intricate regulation and cellular interactions that occur in the testis provide multiple distinct targets, by which toxicants can disrupt spermatogenesis $(1,2)$. Many recent in vivo and in vitro studies demonstrated that most nanoparticles (NPs) have an adverse or toxic effect on male germ cells $(3,4)$. NPs are materials with at least one dimension $\leq 100 \mathrm{~nm}$, and this large surface-to volume ratio results in unique characteristics compared to their corresponding bulk materials (5). The administration of

${ }^{1}$ Cell \& Molecular Research Center, Faculty of Medicine, Ahvaz Jundishapur University of Medical Sciences, Ahvaz, Iran, ${ }^{2}$ Department of Anatomical Sciences, Faculty of Medicine, Ahvaz Jundishapur University of Medical Sciences, Ahvaz, Iran, and ${ }^{3} \mathrm{Fertility}$, Infertility and Perinatology Research Center, Ahvaz Jundishapur University of Medical Sciences, Ahvaz, Iran

Address for correspondence: L. Khorsandi, Cell \& Molecular Research Center, Faculty of Medicine, Ahvaz Jundishapur University of Medical Sciences, P.O. Box: 61335, Ahvaz, Iran.

Phone: +98.611.3720458, Fax: +98.611.3336380

Acknowledgement: This study is part of Ms. C thesis for Nahid MoradiGharibvand and was supported by a Grant (CMRC-9423) from the research council of the Ahvaz Jundishapur University of Medical Sciences in 2016.
NPs to mice resulted in their accumulation in the various tissues including the brain and the testis, indicating that they could easily pass through the blood-brain and blood-testis barriers $(6,7)$.

Metal NPs and their oxides have a considerable number of present and future applications in the medical and industrial fields (8). Among the various metal nanomaterials, titanium dioxide nanoparticles $\left(\mathrm{NTiO}_{2}\right)$ are commonly used in industry, surface coating materials, consumer products including food and biocides. Exposure to $\mathrm{NTiO}_{2}$ is not only common within the workplace, but also occurs through water, food, and cosmetics and so on (9). In vitro studies also showed that $\mathrm{NTiO}_{2}$ induces cellular toxicity of reproductive system (10-14). It has been revealed that $\mathrm{NTiO}_{2}$ could be absorbed by Leydig cells in male offspring, and induce histological changes in seminiferous tubules (15).

There are many qualitative studies of testis after NPs treatment, but the stereological aspects of NPs effects on seminiferous tubule and Leydig cells have received little attention. Thus, the present study investigated the TNPs effects on total volumes of testis, seminiferous tubules and interstitial tissue as well as total Leydig cell numbers.

\section{Materials and methods}

\section{Animals}

In this study, 32 healthy adult male NMRI (Naval Medical Research Institute) mice (6-8 weeks old, 25-30 g) were used. We performed this study according to the guidelines of the insti- 
tution's Animal Ethics Committee (approve number: IR.AJUMS. REC.1394.541). The animals were kept under standard laboratory conditions $(12 \mathrm{~h}$ dark and $12 \mathrm{~h}$ light cycle, relative humidity of 50 $\pm 5 \%$ and $22 \pm 3{ }^{\circ} \mathrm{C}$ ) for at least 1 week before the experiment and those conditions were preserved until the end of the experiment. Animal cages were kept clean, and commercial food (pellet) and water were provided ad libitum.

\section{Experimental design}

The mice were randomly divided into the four groups, all of which contained eight animals. The doses of TNP (Sigma) were selected according to previous studies that demonstrated a significant toxicity in rodents $(16,17)$.

Experimental groups (TNP-1, TNP-2 and TNP-3) received 75, 100 and $300 \mathrm{mg} / \mathrm{kg}$ TNP for 35 consecutive days, respectively. The duration time of treatment was selected according to the timing of mouse spermatogenesis (18). The control group received saline orally for 35 consecutive days. One day after the last administration, after blood sampling, the mice were sacrificed by cervical dislocation under ether anaesthesia. Body and testis weight were recorded at the time of the sacrifice. Right testis from each animal was fixed in bouin's solution for measurement of total volumes of testis, seminiferous tubules and interstitial tissue as well as total number of Leydig cells by stereological methods. The left testicles were homogenized for measurement of testosterone concentration.

After dissection, the testis was weighed, and the primary volume (V primary) was measured using the immersion method (19). Briefly, a container with distilled water was placed on the scale and weighed, and then the testicles suspended by a thin thread were immersed in the container so that it was fully covered by water and did not touch the bottom of the container. The new weight in grams, minus the weight of the container and water, divided by the specific gravity of distilled water (1.0) was the volume of the testis in cubic centimetres. The final volume of the testis should be estimated in a stereological study to prevent reference trap.

\section{TNP preparation}

One gr of $\mathrm{NTiO}_{2}$ nanopowder (Sigma) was added to $100 \mathrm{ml}$ BSA (bovine serum albumin) solution. BSA solution at a con- centration of $40 \mathrm{mg} / \mathrm{ml}$ was prepared by dissolving the powder in Milli-Q water at $\mathrm{pH} 4.7$ (isoelectric point of BSA). The mixture was then ultrasonicated for $1 \mathrm{~h}$. A stock solution of $1 \mathrm{mg} / \mathrm{ml} \mathrm{TNP}$ was prepared in the BSA solution. The mixture was dispersed for $10 \mathrm{~min}$ by using an ultrasonicator and kept at $4{ }^{\circ} \mathrm{C}$. The stock solution was stable for at least 7 days at $4{ }^{\circ} \mathrm{C}$. Just before each administration, the stored solution was diluted and sonicated for 15 minutes. Atomic force microscopy (AFM) was used to characterize the prepared TNP.

\section{Testosterone assay}

The blood samples were collected in heparinized centrifuge tubes and centrifuged to obtain serum. Serum testosterone concentration was measured by radio immunoassay (RIA) method. Testosterone was also extracted from testes as previously described (20). Briefly, testes were homogenized by sonication and centrifuged at $5900 \times \mathrm{g}$ for $5 \mathrm{~min}$. The supernatant was combined with an equal volume of ethyl acetate, and the organic phase was dried under a stream of $\mathrm{N} 2$ gas at room temperature and reconstituted in $1 \times$ PBS. The concentration of testosterone by this procedure was estimated by RIA.

\section{Morphometry}

Diameters of the seminiferous tubules and the lumen diameter were measured by using Motic Images Plus 2.0 image analysis software. The height of the seminiferous epithelium was calculated by subtracting the lumen diameter from the tubule diameter. For each animal, 150 tubules were analysed. Finally, a "blind" method has been used for slides reading (21).

\section{Stereological assessments}

\section{Histology and sampling of sections}

Each testis was embedded randomly in paraffin and sectioned exhaustively into $5 \mu \mathrm{m}$-thick sections. Figure 1 illustrates the sampling of sections. Three sections were collected onto each glass slides. With a random start between the first 20 sections, every 20 th section was sampled (the primary sections). In addition, two sections ahead of every primary section were sampled as the reference section. Because every section was $5 \mu \mathrm{m}$ thick, it follows
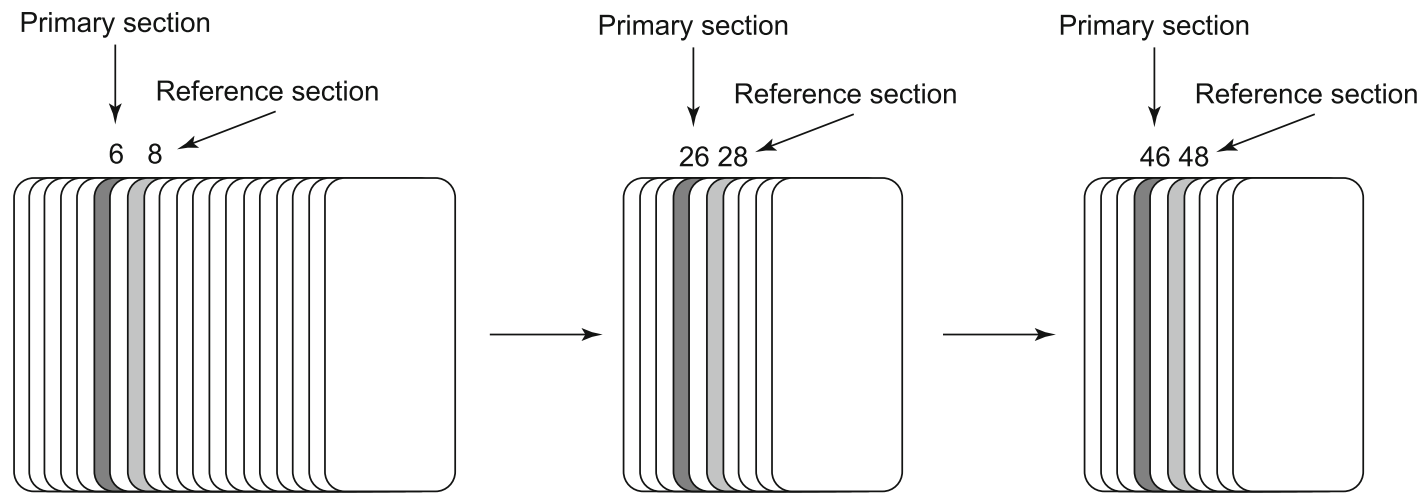

Fig. 1. Sampling method of histological sections is shown. 
that there was $100 \mu \mathrm{m}$ between the primary sections and $10 \mu \mathrm{m}$ between a primary section and the corresponding reference section. All primary and reference sections were stained with hematoxylin and eosin (H \& E).

\section{Total volumes of testis, seminiferous tubules and interstitial tissue}

Using step-lengths of $750 \mu \mathrm{m}$ in the $x$-direction $(\Delta x)$ and $550 \mu \mathrm{m}$ in the $y$-direction $(\Delta y)$, all primary sections from each testis were systematically examined. A point-counting grid with 108 points, 1 of them encircled, was applied (Fig. 2A). Moving through all primary sections from the testicles, we counted how many times 1 of the 108 points hit a seminiferous tubules or interstitial tissue. Simultaneously, we counted how many times the encircled point hit testis tissue (seminiferous tubules and interstitial tissue). The values for the total volume of testis, seminiferous tubules and interstitial tissue were then calculated based on the Cavalieri principle $(22,23)$.

1) $\mathrm{V}(\mathrm{Tes})=\mathrm{a} / \mathrm{p}(\mathrm{Tes}) \times \mathrm{N}(\mathrm{p}-\mathrm{p}) \times \mathrm{T} \times \Sigma \mathrm{P}(\mathrm{Tes})=0.095 \mathrm{~mm} 3$ $\times \Sigma \mathrm{P}(\mathrm{Tes})$

Where $\mathrm{V}$ (Tes) is the total volume of testis, a/p (Tes) is the area per point (in this case $\Delta x \times \Delta y$ because only one point in the grid was used to count points that hit testis), $N(p-p)$ is the number of sections between the primary sections (20 sections in this case), $\mathrm{T}$ is the section thickness $(5 \mu \mathrm{m})$, and $\Sigma \mathrm{P}$ (Tes) is the total number of points that hit testis.

2) $\mathrm{V}(\mathrm{Sem})=\mathrm{a} / \mathrm{p}(\mathrm{Sem}) \times N(p-p) \times T \times \Sigma P($ Sem $)=0.095 \times 103$ $\mathrm{mm} 3 \times \Sigma \mathrm{P}(\mathrm{Sem})$

Where $\mathrm{V}(\mathrm{Sem})$ is the total volume of seminiferous tubules, $\mathrm{a} / \mathrm{p}(\mathrm{Sem})$ is the area per point and $\Sigma \mathrm{P}(\mathrm{Sem})$ is the total number of points that hit the seminiferous tubules.

3) $\mathrm{V}($ Int $)=\mathrm{a} / \mathrm{p}($ Int $) \times \mathrm{N}(\mathrm{p}-\mathrm{p}) \times \mathrm{T} \times \Sigma \mathrm{P}($ Int $)=0.095 \times 103 \mathrm{~mm} 3$ $\times \Sigma \mathrm{P}($ Int $)$

Where $\mathrm{V}$ (Int) is the total volume of interstitial tissue, $\mathrm{a} / \mathrm{p}$ (Int) is the area per point and $\Sigma \mathrm{P}$ (Int) is the total number of points that hit the interstitial tissue.

Tissue shrinkage influences all stereological size estimators whether it is distance, surface area, or volume. There is no exact

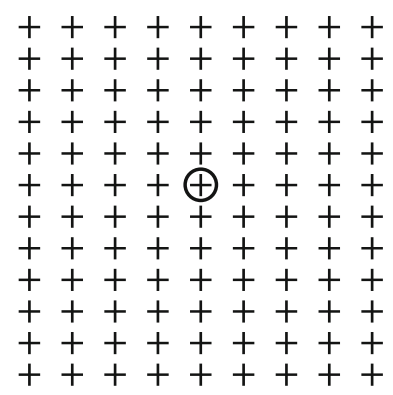

Fig. 2. Point counting grade (A) and unbiased counting frame (B).
Tab. 1. Body and testis weight of control and experimental groups.

\begin{tabular}{lccc}
\hline Group & $\begin{array}{c}\text { Body weight } \\
(\mathrm{g})\end{array}$ & $\begin{array}{c}\text { Testis weight } \\
(\mathrm{mg})\end{array}$ & $\begin{array}{c}\text { Testis/body weight } \\
(\mathrm{mg} / \mathrm{g})\end{array}$ \\
\hline Control & $29.4 \pm 3.3$ & $131.7 \pm 6.3$ & $4.47 \pm 0.83$ \\
TNP-1 & $29.2 \pm 5.2$ & $130.1 \pm 10.4$ & $4.45 \pm 0.95$ \\
TNP-2 & $29.3 \pm 4.6$ & $104.7 \pm 7.8^{*}$ & $3.57 \pm 0.34^{*}$ \\
TNP-3 & $29.5 \pm 3.9$ & $90.5 \pm 9.9^{* *}$ & $3.06 \pm 0.25^{* *}$ \\
\hline
\end{tabular}

Values expressed as mean \pm SD for 8 mice. $* \mathrm{p}<0.05$

unbiased way to obtain information about tissue deformation during tissue fixation and processing. The area of a piece of testis tissue before and after fixation/processing may be estimated, and the tissue shrinkage can be calculated as (24):

$$
1-\left(\frac{\text { A-after }}{\text { A- before }}\right)^{1.5}
$$

\section{Total number of Leydig cells}

In another session, the sampling within the primary sections was performed, but an unbiased counting frame (Fig. 2B) was now attached to the monitor. The rules of the counting frame define objects completely outside the frame or objects that touch the exclusion lines (the full lines in the Figure 2B) as being outside the frame, whereas objects that are completely within the frame or touch only the inclusion lines (the dashed lines in the Figure 2B) are defined as being within the frame. We applied the dissector principle (Sterio, 1984) to count the Leydig cells.

Whenever the Leydig cell was sampled by the counting frame, the corresponding position in the reference section was located with the other microscope, and we determined whether the Leydig cell was also visible in the reference section. The Leydig cell was counted if it appeared in the primary section, but not in the reference section. Because the sampling of sections as well as the within section sampling were performed with known sampling fractions, the total number of Leydig cells can be calculated according to the fractionator's principle $(22,23)$ from:

$\mathrm{N}($ Ley $)=\frac{\mathrm{N}(\mathrm{p}-\mathrm{p})}{\mathrm{N}(\mathrm{p}-\mathrm{r})} \times \frac{\Delta \mathrm{x} \times \Delta \mathrm{y}}{A(\text { frame })} \times \Sigma \mathrm{Q}^{-}($Ley $)=34.53 \times \sum \mathrm{Q}^{-}($Ley $)$

Where $\mathrm{N}$ (Ley) is the total number of islets in the pancreas, $\mathrm{N}(\mathrm{p}-\mathrm{p})$ is the number of sections between the primary sections, $\mathrm{N}(\mathrm{p}-\mathrm{r})$ is the number of sections between a primary section and the corresponding reference section (two in this case), $\Delta x$ and $\Delta$ $y$ are the step lengths, A(frame) is the area of the counting frame corrected for magnification (412.674 $\mu \mathrm{m} 2)$, and $\Sigma$ Q- (Ley) is the total number of Leydig cells counted in one testis (23).

\section{Results}

\section{Organ weight}

No significant changes were observed in body weight of the experimental groups. Weight of testicles in the TNP-1 and TNP-2 groups was slightly lower than in the control group $(p>0.05)$. A significant reduction in testicular weight was observed in the TNP3 ( $<<0.05$ ) group (Tab. 1). Relative testes weight was obtained by dividing testes weight by body weight. Relative testes weight 

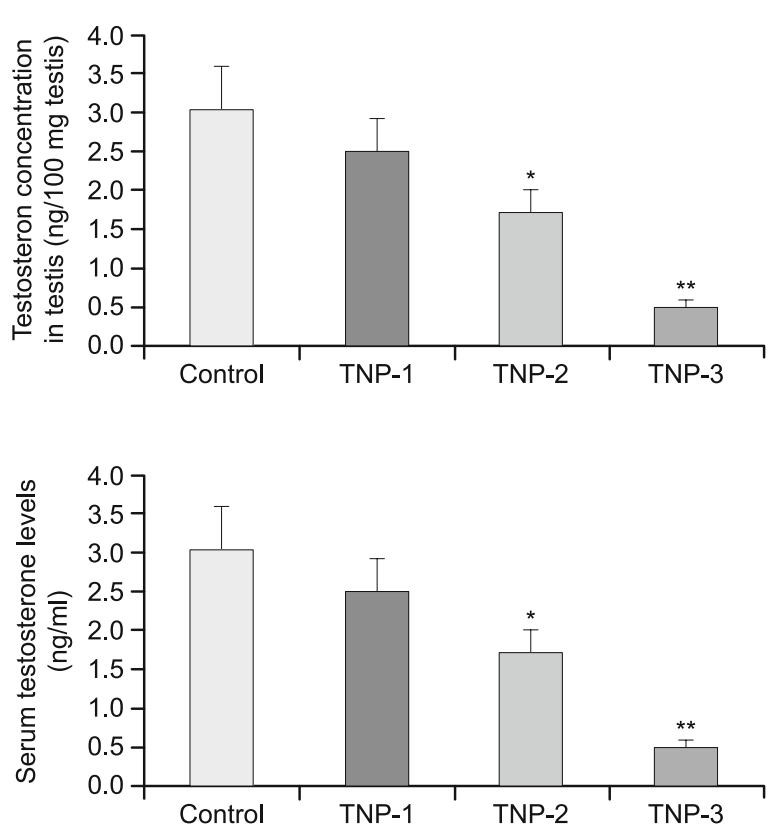

Fig. 3. Testosterone concentrations in control and experimental groups. Values are expressed as mean \pm SD for 8 mice. ${ }^{*} p<0.05$, ${ }^{* *} p<0.01$.

in TNP-3 group was significantly lower than in the control $(\mathrm{p}<$ 0.05). These results are shown in Table 1.

\section{Testosterone assay}

To determine whether TNP affect Leydig cells function, the serum and testis testosterone concentrations were assessed. As illustrated in Figure 3, concentration of the serum and testis testosterone in TNP-1 group was slightly lower than in the control group $(\mathrm{p}<0.05)$. In TNP-2 and TNP-3 animals, testosterone levels were significantly decreased compared to the control group.

\section{Morphometry}

TNP-1 group showed no significant alteration in testicular parameters compared to the control group. Diameters of the semi-

Tab. 2. Morphometrical parameters in control and experimental groups.

\begin{tabular}{lcc}
\hline Group & STD $(\mu \mathrm{m})$ & SEH $(\mu \mathrm{m})$ \\
\hline Control & $210.4 \pm 10.0$ & $69.2 \pm 4.6$ \\
TNP-1 & $209.3 \pm 11.2$ & $68.9 \pm 5.9$ \\
TNP-2 & $167.6 \pm 14.6^{*}$ & $59.4 \pm 6.1^{*}$ \\
TNP-3 & $110.1 \pm 13.7^{* *}$ & $55.3 \pm 4.1^{* *}$ \\
\hline \multicolumn{2}{l}{ Values expressed as mean \pm SD for 8 mice. ${ }^{*} \mathrm{p}<0.05,{ }^{* *} \mathrm{p}<0.01$}
\end{tabular}

Tab. 3. Sterological parameters in control and experimental groups.

\begin{tabular}{lccc}
\hline \multirow{2}{*}{ Group } & Leydig cell number $\left(10^{6}\right)$ & \multicolumn{2}{c}{ Volume } \\
\cline { 3 - 4 } & $2.43 \pm 0.31$ & $126.3 \pm 12.2$ & Seminiferous tubules \\
\hline Control & $2.36 \pm 0.43$ & $125.8 \pm 9.8$ & $102.6 \pm 11.2$ \\
TNP-1 & $1.65 \pm 0.84^{*}$ & $110.7 \pm 11.8^{*}$ & $100.4 \pm 8.7$ \\
TNP-2 & $0.76 \pm 0.26^{* *}$ & $84.1 \pm 9.9^{* *}$ & $81.7 \pm 7.4^{*}$ \\
TNP3 & & $54.7 \pm 7.2^{* *}$ \\
\hline
\end{tabular}

Values expressed as mean \pm SD for 8 mice. $* \mathrm{p}<0.05, * * \mathrm{p}<0.01$ niferous tubules and height of the seminiferous epithelium were significantly decreased in both TNP-2 and TNP-3 groups. The results of morphometric studies are shown in Table 2.

\section{Stereology}

The present study confirmed a $21 \%$ of tissue shrinkage in paraffin embedding. This shrinkage was considered when the final results were reported. In TNP-1 group, total volumes of testis, seminiferous tubules and interstitial tissue were similar to the control group. Total Leydig cell numbers were slightly lower than the control group.

In TNP-2 group, total testis volume was slightly decreased ( $\mathrm{p}$ $>0.05$ ). Total volume of seminiferous tubules was significantly decreased, while total volume of interstitial tissue was significantly increased. Total Leydig cell numbers were also significantly decreased when compared to the control group.

In TNP-3 group, total testis volume and total seminiferous epithelium volume were significantly lower than in the control group $(p<0.05)$. Total interstitial tissue volume showed a significant increase in comparison to control group $(p<0.05)$. Total Leydig cell numbers were significantly decreased $(\mathrm{p}<0.01)$. These results are reported in Table 3.

\section{Discussion}

Based on stereological methods (such as fractionators sampling and disector counting) we found a reduction in the total volume of seminiferous tubules in TNP treated mice. This reduction was significant in TNP-3 group. TNP treatment also induced a reduction in seminferous tubule diameter and seminiferous epithelium height. Talebi et al showed that zinc oxide nanoparticles could decrease seminiferous tubule diameter and seminiferous epithelim height (21). It is well known that increase in seminiferous tubule diameter is indicative of fluid retention resulting from an impaired emptying through the efferent ducts, whereas decrease in seminiferous diameter may indicate germ cell loss (25).

Previous studies revealed that NPs had the capacity to penetrate the blood-testis barrier and some of them had toxic action on male germ cells $(26,27)$. Braydich-Stolle et al showed that mammalian spermatogonial stem cells were sensitive to Ag-NPs (4). Thus, the reduction in the total volume of seminiferous tubules may have been a consequence of the germ cells loss induced by TNPs.

The total volume of interstitial tissue was increased in experimental groups. This may be a consequence of the reduction in the volume of seminferous tubule or seminiferous tubules diameter. Another possibility is that TNPs may induce inflammation or 
edema in interstitial tissue. However, any unusual leukocyte infiltration in this area was not observed. In spite of an increase in the total volume of interstitial tissue, the number of Leydig cells was considerably decreased in present study. Leydig cells synthesize and secrete testosterone to blood stream and testicular tissue. The presence of testosterone is essential for normal function and survival of the germ cells in seminiferous tubules (28). When the testicular environment cannot support spermatogenesis, specific mechanisms leading to germ cell death are activated (29). TNPs also caused a significant decrease in serum and testis tissue testosterone concentrations. Komatsu et al reported that titanium oxide and carbon black nanoparticles were taken up by mouse Leydig TM3 cells, and affected their viability, proliferation and gene expression (30). Yoshida et al reported that exposure to diesel exhaust nanoparticles induce Leydig cell degeneration, increase the number of damaged seminiferous tubules, and reduce daily sperm production (31).

Additionally, the reduction in testis weight also indicates that TNP could induce testicular cell loss including germ cells and somatic cells. As mentioned above, Leydig cell numbers were decreased in TNPs treated mice. The reduction in the number of Leydig cells can lead to decrease in testosterone levels and consequently germ cell apoptosis.

Apoptotic effects of TNP have also been reported in other researches. Kang et al (2009) have shown that TNP induced apoptosis in phytohemagglutinin-stimulated human lymphocytes (32). Orazizadeh et al. have demonstrated that TNP induced apoptosis in liver and testicular tissues $(33,34)$. Park et al. showed that TNP induced apoptosis and oxidative stress in cultured BEAS2B cells (35).

Diminution in the testis weights and relative testis weight in TNP-treated mice indicates toxic action of TNP on mouse testicles. As the body growth was not significantly altered in TNPtreated mice, the effect of TNP on the testis may be due to its specific toxic effect on the target organ and not the result of its general toxicity.

In summary, this study had proved that TNP caused dosedependent reduction in testis weight, total volume of testis, total volume of seminiferous tubules, seminiferous tubule diameter, seminiferous epithelium height and total number of Leydig cells. The reduction in the number of Leydig cells lead to decrease in testosterone concentrations and this can induce germ cell death. Increase in germ cell loss can lead to the decrease in seminiferous tubule volume and diameter, testis volume and weight. However, to state the mechanism by which TNP exerts its effects needs more investigations.

\section{References}

1. Franca LR, Ghosh S, Ye SJ, Russell LD. Surface and surface to volume relationships of the Sertoli cells during the cycle of the seminiferous epithelium in the rat. Biol Reprod 1993; 49 (6): 1215-1228.

2. Boekelheide K, Fleming SL, Johnson KJ, Patel SR, Schoenfeld HA. Role of Sertoli cells in injury-associated testicular germ cell apoptosis. Exp Biol Med 2000; 225 (2): 105-115.
3. Braydich-Stolle LK, Lucas B, Schrand A et al. Silver nanoparticles disrupt GDNF/Fyn kinase signaling in spermatogonial stem cells. Toxicol Sci 2010; 116 (2): 577-589.

4. Braydich-Stolle L, Hussain S, Schlager JJ, Hofmann MC. In Vitro cytotoxicity of nanoparticles in mammalian germline stem cells. Toxicol Sci 2005; 88 (2): 412-419.

5. Roduner E. Size matters: why nanomaterials are different. Chem Soc Rev 2006; 35 (7): 583-592.

6. Borm PJ, Kreyling W. Toxicological hazards of inhaled nanoparticles potential implications for drug delivery. J Nanosci Nanotechnol 2004; 4 (5): 521-531.

7. Chen Y, Xue Z, Zheng D et al. Sodium chloride modified silica nanoparticles as a non-viral vector with a high efficiency of DNA transfer into cells. Curr Gene Ther 2003; 3(3): 273-279.

8. Tyner KM, Schiffman SR, Giannelis EP. Nanobiohybrids as delivery vehicles for camptothecin. J Controlled Release 2004; 95 (3): 501-514.

9. Weir A, Westerhoff P, Fabricius L, Hristovski K, von Goetz N. Titanium dioxide nanoparticles in food and personal care products. Environ Sci Technol 2012; 46: 2242-2250.

10. Gao GD, Ze YG, Li B et al. The ovarian dysfunction and its geneexpressed characteristics of female mice caused by long-term exposure to titanium dioxide nanoparticles. J Hazard Mater 2012; 243: 19-27.

11. Gao GD, Ze YG, Zhao XY et al. Titanium dioxide nanoparticle-induced testicular damage, spermatogenesis suppression, and gene expression alterations in male mice. J Hazard Mater 2013; 258: 133-143.

12. Zhao XY, Ze YG, Gao GD et al. Nanosized TiO2- induced reproductive system dysfunction and its mechanism in female mice. PLoS One 2013; 8: e59378

13. Meena R, Kajal K, Paulraj R. Cytotoxic and genotoxic effects of titanium dioxide nanoparticles in testicular cells of male Wistar rat. Appl Biochem Biotechnol 2015; 175: 825-840.

14. Hong F, Zhao X, Chen $\mathrm{M}$ et al. TiO2 nanoparticles-induced apoptosis of primary cultured Sertoli cells of mice. J Biomed Mater Res A 2016; 104 (1): 124-135.

15. Takeda K, Suzuki K, Ishihara A et al. Nanoparticles transferred from pregnant mice to their offspring can damage the genital and cranial nerve systems. J Health 2009; 55: 95-102.

16. Xu J, Shi H, Ruth M et al. Acute toxicity of intravenously administered titanium dioxide nanoparticles in mice. PLoS One 2013; 8 (8): e70618.

17. Vasantharaja D, Ramalingam V, Reddy GA. Oral toxic exposure of titanium dioxide nanoparticles on serum biochemical changes in adult male Wistar rats. Nanomed J 2015; 2 (1): 46-53.

18. Hess RA, Chen PP. Computer of germ cells in the cycle of the seminiferous epithelium and prediction of changes in the cycle duration in animals commonly used in reproductive biology and toxicology. J Androl 1992; 13: 185-190.

19. Scherle W. A simple method for volumetry of organs in quantitative Stereology. Mikroskopie 1970; 26 (1): 57-60.

20. Habert R, Picon R. Control of testicular steroidogenesis in foetal rat: effect of decapitation on testosterone and plasma luteinizing hormone-like activity. Acta Endocrinol 1982; 99 (3): 466-473.

21. Talebi AR, Khorsandi L, Moridian M. The effect of zinc oxide nanoparticles on mouse spermatogenesis. J Assist Reprod Genet 2013; 30 (9): 1203-1209. 


\section{9-664}

22. Gundersen HJ, Jensen EB. The efficiency of systematic sampling in stereology and its prediction. J Microsc 1987; 147 (3): 229-263.

23. Bock T, Pakkenberg B, Buschard K. Inctrased islet volume but unchanged islet number in ob/ob mice. Diabetes 2003; 52 (7): 1716-1722.

24. Nyengaard JR. Stereologic methods and their application in kidney research. J Am Soc Nephrol 1999; 10 (5): 1100-1123.

25. Moffit JS, Bryant BH, Hall SJ, Hall SJ. Dose-dependent effects of Sertoli cell toxicants 2, 5-hexanedione, carbendazim, and mono- (2-ethylhexyl) phthalate in adult rat testis. Toxicol Pathol 2007; 35 (5): 719-727.

26. Borm PJ, Kreyling W. Toxicological hazards of inhaled nanoparticles potential implications for drug delivery. J Nanosci Nanotechnol 2004; 4 (5): 521-531.

27. Chen Y, Xue Z, Zheng D et al. Sodium chloride modified silica nanoparticles as a non-viral vector with a high efficiency of DNA transfer into cells. Curr Gene Ther 2003; 3 (3): 273-279.

28. Sinha Hikim AP, Swerdloff RS. Hormonal and genetic control of germ cell apoptosis in the testis. Rev Reprod 1999; 4 (1): 38-47.

29. Hardy MP, Gao HB, Dong Q, Chai WR. Stress hormone and male reproductive function. Cell Tissue Res 2005; 322 (1): 147-153.
30. Komatsu T, Tabata M, Kubo-Irie M et al. The effects of nanoparticles on mouse testis Leydig cells in vitro. Toxicol in Vitro 2008; 22 (8): 1825-1831.

31. Yoshida S, Sagai M, Oshio S et al. Exposure to diesel exhaust affects the male reproductive system of mice. Int J Androl 1999; 22 (5): 307-315.

32. Kang SJ, Kim BM, Lee YJ, Hong SH, Chung HW. Titanium dioxide nanoparticles induce apoptosis through the JNK/p38-caspase-8-Bid pathway in phytohemagglutinin-stimulated human lymphocytes. Biochem Biophys Res Commun 2009; 386 (4): 682-687.

33. Orazizadeh M, Fakhredini F, Mansouri E, Khorsandi L. Effect of glycyrrhizic acid on titanium dioxide nanoparticles-induced hepatotoxicity in rats. Chem Biol Interact 2014; 220: 214-221.

34. Orazizadeh M, Daneshi E, Hashemitmar M, Absalan F, Khorsandi L. Protective effect of beta-carotene against titanium dioxide nanoparticles induced apoptosis in mouse testicular tissue. Andrologia 2015; 47 (7): 816-825.

35. Park EJ, Yi J, Chung KH et al. Oxidative stress and apoptosis induced by titanium dioxide nanoparticles in cultured BEAS-2B cells. Toxicol Lett 2008; 180 (3): 222-229. 